Article

\title{
Condition Verified: On Photography, Trans Visibility, and Legacies of the Clinic
}

\author{
Chase Joynt ${ }^{1, *}$ and Emmett Harsin Drager ${ }^{2}$ \\ 1 The Department of Gender Studies, University of Victoria, Victoria, BC V8P 5C2, Canada \\ 2 Department of American Studies \& Ethnicity, University of Southern California, Los Angeles, CA 90089, \\ USA; harsindr@usc.edu \\ * Correspondence: joynt@uvic.ca
}

Received: 1 September 2019; Accepted: 31 October 2019; Published: 13 November 2019

check for updates

\begin{abstract}
We approach this paper with a shared investment in historical and contemporary representations of trans and gender non-conforming people, and our individual research in the archives of early US Gender Clinics. Together, we consider what is at stake-or what might be possible-when we connect legacies of photography used as diagnostic tools in gender clinics with snapshots of early, community-based gatherings, and the presence of trans people in contemporary art. From the archives of Robert J. Stoller and photos of Casa Susanna, to the collaborative photography of Zackary Drucker and Amos Mac, and the biometric data art-theory experiments of Zach Blas, we engage a series of image-based projects, which animate underlying questions and socio-political debates about the politics of visuality, and visibility's impact on trans and gender non-conforming people. Moreover, we argue that rhetorical strategies of proof-from conditions verified in clinics to shared existence through photography—are tethered to, and thus trapped by, the logics and discipline of legibility and re-institutionalization.
\end{abstract}

Keywords: gender clinics; photography; transgender; Robert J. Stoller; visibility; opacity; Casa Susanna; Zackary Drucker; Amos Mac

\section{Preface}

A photograph is a secret about a secret. The more it tells you, the less you know.

—Diane Arbus, Artforum May, 1971

We approach this paper with a shared investment in historical and contemporary representations of trans and gender non-conforming people, and our individual research in the archives of early US Gender Clinics. Together, we consider what is at stake-or what might be possible-when we connect the legacies of photography used as diagnostic tools in gender clinics to snapshots of early community-based gatherings, and the presence of trans people in contemporary art. We do not imagine this writing to be an exhaustive account of such approaches, but, rather, a collaborative musing on a series of aesthetic projects, which animate underlying questions and socio-political debates about the politics of visuality, and visibility's impact on trans and gender non-conforming people. Moreover, we argue that rhetorical strategies of proof-from conditions verified in clinics to shared existence through photography - are tethered to, and thus trapped by, the logics and discipline of legibility and re-institutionalization.

\section{Photography and the Clinic}

"The Stoller Papers" in UCLA's Special Collection contains ninety linear feet of documents from the life of Dr. Robert J. Stoller, a professor of psychiatry at the University of California, Los Angeles, 
and one of the founding members of UCLA's Gender Identity Research Clinic. The collection, donated in 1995 by Stoller's wife, Sybil, is organized into five categories: correspondence, presentation files, publication files, reprint files, and research files. Throughout these various categories sit an array of photographs - of prospective patients, of friends and colleagues, and of pornography and kink from Stoller's research on perversion-however, absent from the archive, is any photograph of Stoller himself.

In a letter written to a French publisher in 1979, Stoller wrote: "You should know that I never offer my picture for public use, trying always to remain invisible as a person. In that way, both my research and pleasure in privacy are retained" (Stoller Papers 1942-1991). Set on maintaining his privacy, Stoller refused to include any image of himself in his books. Remarkably, even today, in the age of Google Images, he remains faceless.

Dr. Stoller, often credited for coining the term "gender identity," spent the bulk of his career working with patients who were deemed to have deviant genders (Meyerowitz 2002, p. 115). A prolific writer, he authored nine books and more than one hundred articles about sex, gender, sexuality, and perversion. Whereas other university gender clinics, such as Johns Hopkins and Stanford 'treated' transsexuality with surgery and hormones, Stoller and the doctors at UCLA championed psychotherapy as the most appropriate diagnostic method.

To appraise the unique way that photography surfaces — or fails to surface - in the archives of gender clinics, we must consider the role of the visual in medical diagnoses. In Western epistemology, the visual has long been privileged as the site of truth. Indeed, the Greek word for knowledge, eidenai, translates to "the state of having seen" (Jay 1994, p. 24). In The Birth of the Clinic, Michel Foucault (1994) argues that modern medicine is formulated by a particular type of looking-what he deems the "gaze". A clinical professional is assumed to hold the ability to keenly observe the body as an object, and subsequently relay the truth of that body in objective language. Thus, for Foucault, the gaze is co-constituted by both seeing and saying. In modern medicine, pathology is understood to be observable, if only the doctor knows how and where to look.

The clinical gaze was extended with the advent of photography, as observations could occur in real time and then again, via still images (see: Singer 2006). As such, photography became a popular method in sexological research to document bodies deemed abnormal. What doctors perceived to be visual indications of deviance could be captured in photographs, catalogued in archives, and.circulated for further research and opinion. Writing in 1990, Jennifer Terry elaborates that "photographs were explicitly intended to supplement other physical data and to act as diagnostic instruments for correlating body form with behavior" (Terry 1990, p. 196).

As Hilary Malatino (2019) presents in Queer Embodiment: Monstrosity, Medical Violence, and Intersex Experience, medical photography and its aesthetic qualities—the "medical mugshot" — were historically used to actively dehumanize trans, intersex, and gender non-conforming subjects. Patients were often posed against a blank wall, with their faces obscured or covered by a black bar. Occasionally, the hand of a doctor would intervene in the photographic plane, pointing to particular qualities on the body or holding them up on display. According to Malatino, the doctors always remained faceless. Borrowing from Donna Haraway's concept of the "modest witness," Malatino (2019, p. 138) elaborates that the doctor "must inhabit the space of the unmarked, must be the witness who is never himself witnessed." Stoller's aversion to being photographed resonates with Haraway's "modest witness," positioning him as the doctor who must remain faceless in pursuit of "objectivity" within the organizing logics of the medical gaze.

In contrast to Stoller's own facelessness, his collection includes innumerable snapshots of transsexual people, often paper-clipped to letters from individuals hoping to become patients of the clinic. One can assume that the individuals in these photographs were not accepted as patients, as the files of those who were offered services are restricted, under archival provisions of patient-physician privilege (Joynt and Schilt 2015). What distinguishes photographs in Stoller's collection from other clinical archives is that they are home snapshots-not taken by medical professionals-included to 
bolster one's case of gender deviance, and to prove the viability and necessity of treatment. In one photograph, mailed with a three-page autobiographical letter, the individual stands posed in a bikini. They write, "Enclosed you will see one of my pictures in bathing suit similar to a bikini. Note my developed breasts, and my whole general feminine delineations. Note specifically how my small penis is almost invisivle [sic] through the bikini" (Stoller Papers 1942-1991). While the letter speaks to the potential patient's lifelong cross-gender identification, the photograph is provided as the visual evidence of their claim.

As Jennifer Terry (1990) explains in An American Obsession, it was common for photography in sex/sexuality research to be paired with autobiographical writing. In the 1930s, the Committee for the Study of Sexual Variants studied homosexuals in New York City; in addition to psychiatric interviews, masculinity and femininity tests, and physical examinations, the study's participants were also photographed. Terry (1990, p. 196) elaborates how visual means of documenting bodily difference (X-rays, photographs, and drawings) were analyzed alongside autobiographical accounts:

The imperative to survey bodies was fueled by a kind of scientific scopophilia: the pleasures of viewing were deeply tied both to a positivist quest for the truth in physical evidence and to a desire to read the body for indications of sexual practice. But the importance given to the subject's own stories indicates that researchers believed the body alone could not provide adequate information about the causes and defining characteristics of homosexuality.

From the inception of sex, gender, and sexuality research, the visual register has remained sutured to the textual and autobiographical (for more on trans medical narratives and the cultural/scientific production of truth, see: Joynt and Schilt 2018; Anex-Ries et al.).

The dialectical relationship between autobiography and photography is further substantiated by the widespread practice of including photographs in memoirs by trans and gender non-conforming people. The inclusion of photographic gender "evidence" in autobiographies mimics the verification-based, use-value of clinical photography in medical case files. Here, subjects are complicit in suggesting that a kind of truth can be discerned, simply through close observation. The ability to provide evidence from both one's past and present further bolstered one's claim to be legitimately, rather than performatively or, perhaps, pathologically, transsexual. The very definition of "gender identity disorder" reads: "a persistent sense of discomfort and inappropriateness about one's anatomical gender" (American Psychiatric Association 1980). What better way to show the persistence of one's cross-gender identification than to reveal its existence in childhood, through photographic evidence?

A third photographic category sits alongside the body snapshots and childhood photographs sent to doctors at the clinic - the glamour shot. Housed at the Kinsey Institute in Bloomington, Indiana, is the archival collection of Dr. Harry Benjamin, author of the groundbreaking book The Transsexual Phenomenon (Benjamin et al. 1966) and one of the most influential doctors in the history of trans therapeutics. In a folder labeled "transsexual and transvestite photographs," Benjamin stored glamour shots of his patients. Often included on the back of the photographs are small notes of thanks: "To Dr. Benjamin to whom I owe a new life" and "To my wonderful friend Dr. Harry Benjamin, who by his help, started a chain of events culminating in a new career. I will never forget you."

Similar to the ways in which photographs from childhood have been deployed, as evidence of a "persistent sense of discomfort and inappropriateness about one's anatomical gender," the post-transition glamour shot was used as evidence to validate the success of treatment. A testimony to the hypothesis that, with proper treatment, any transsexual could be happy, thriving, and passing, these photographs made a convincing case for providing transsexuals with access to hormones and surgery. While many doctors were skeptical that a person could successfully live and pass after transition, the transsexual glamour shot became both a persuasive and celebratory document that positioned patients as capable of gender assimilation.

A unifying thread between these three modes of trans photography-the body snapshot, the childhood photograph, and the glamour shot-is the use of captions to provide further context and 
meaning. Whether a type-written description, an autobiographical note, or a handwritten message on the back of the photograph, the captions instruct the viewer-here, we can assume this is the doctor-on what exactly they should be seeing. With the photograph deployed as evidence, the caption serves as a secondary mode of persuasion. Underpinning each textual supplement is the fear, or perhaps simple acknowledgement, that something about the image requires additional explanation, of some meaning that will otherwise slip away. We recognize this self-annotation as a form of secondary citation, a self-crediting that sits both within the logics of medical diagnosis and outside of its rhetorical structure and gaze.

In Camera Lucida, Roland Barthes (2010) distinguishes between the connotative and denotative aspects of a photograph, or what he calls the "stadium" and "punctum". The studium, or connotative meaning, is a direct expression of the photographer's intention. Here, the subject-authored caption is incorporated into the realm of the studium, as it is instructive, much like the lens of the camera, and guides the viewer toward a desired interpretation and resulting conclusion. In contrast, the punctum is what emerges as a piercing point in the image, often by accident-a reality, which we understand the caption perhaps seeks to redirect or abate.

Ontologically, both photography and the sexed body are understood to visually represent inherent truths, intensifying already existing visual economies. In the history of research and treatment of intersex bodies, for instance, visible markers of sex came to determine gendered child rearing and medical intervention. So important was the look of the sexed body, that parents and doctors considered a small phallus reason enough to rear a child as a girl, regardless of chromosomes, hormones, or ongoing identifications.

The body snapshot, childhood photograph, and glamour shot, then, are designed to depict a particular truth about the individual's sex and gender; however, the aforementioned use of captions illustrates that perhaps subjects felt incapable of relaying this supposed truth without added language. If photographs are unable to make a case for the truth of a person's sex without caption, it is not because the individual in the photograph is failing to embody a true sex, but rather because sex and gender must always necessarily be contextualized and narrated (see: Prosser 1998). Just like the sexed body itself, photographs are not self-evidentiary, but, rather, depend on language, culture, and context to negotiate their meaning.

\section{Photography and Community}

I really believe there are things nobody would see if I didn't photograph them.

$$
\text { -Arbus (1973) }
$$

In March 2016, the Art Gallery of Ontario (AGO) opened its largest survey of North American photography, in an exhibition called "Outsiders." In addition to photographs by Diane Arbus and Gordon Parks, and moving-image works by Kenneth Anger and Shirley Clarke, a large collection of never-before-exhibited snapshots from Casa Susanna were on display. Casa Susanna was a vacation hideaway for transvestites and crossdressers in upstate New York during the late 1950s and early 1960s, the same time period as the photographs of patients found, and now referenced, in the Stoller Papers. The Susanna collection re-emerged-or, perhaps, simply emerged-in public, when a collection of photographs was found in the early 2000s at a Manhattan flea market by Michel Hurst and Robert Swope, who published them as a book in 2005 (Hurst and Swope 2005). In the book's introduction, Swope contends, "I believe these are 'witness' pictures" and states that they are "a way of validating identity."

As witnesses to the collection, spectators might surmise that these photos were taken by Susanna residents, for Susanna residents, in celebration of their shared expressive freedom. But what else might we make of these images, now on public display? Alongside the collection, AGO curators offered a "where are they now" series of informative panels about various featured people and cross-dressed identities. Often, didactic panels in gallery settings serve to contextualize the specificity of exhibition content for assumedly lesser-knowing publics. Together, we read these panels as both caption and 
citation: a nod to the illegibility of cross-dressing and transvestism in dominant cis cultures, and a site-specific explanation that is temporally bound.

Understanding the political climate of and for gender transgression in the 1950-1960s, we are left to wonder about the ethics of such historical excavations. Must we - or how might we-account for people's assumedly desired anonymity at the time of their photographic capture (see: Davis 2015)? Just like patients submitting personal snapshots to Stoller's clinic, we cannot presume a desired public-facing intention behind the original making of these images.

At the height of Casa Susanna's hosting, house matriarch and house photographer Susanna Valenti authored essays for Transvestia, a zine published in the 1960-1980s that connected trans, cross-dressing, and gender non-conforming communities. Transvestia was responsible for first publishing early photos from the Susanna collection, as a way of linking those who might be interested in joining the community. The cover of Michael Warner's (2002) book, Publics and Counterpublics, boasts one such picture, staged, and therefore re-visited, in the AGO's exhibition. Scholars of the public sphere contend that counterpublics must always remain in tension, and therefore in contact, with the larger public, and Warner's choice signals a knowing crossing of these boundaries. As such, the Susanna collection at the AGO exists as an example of image-based counterpublic discourse about gender non-conforming subjects, that strategically collides with the mainstream. At the same time, the inclusion of the Casa Susanna exhibit at the AGO reflects the sanitization of once-radical and subversive content that has become legible to-and packaged for-mainstream consumption. We read legibility in these contexts to be a re-institutionalization of photographs in a new setting-from the scrutiny of the clinic to the new inspection by gallery publics.

Writing for CanadianArt, on the tails of the exhibition, Leah Sandals (2016) questioned the ethics of the now very public display of a once-private collection. Speaking to Sandals via email, AGO exhibition curator Sophie Hackett remarked, "Made at a moment when the individuals in question risked much by even attending the resort and documenting themselves 'en femme', the joy and playfulness in these photographs is undeniable. It seemed important to include that [in the exhibition]." A public conversation between University of Toronto professor Elspeth Brown and trans multi-disciplinary artist Zackary Drucker was tethered to the exhibition program, to further animate these questions and debates. Here, we mark a turn toward an additional mode of context through captions, that of embodied narration.

At present, Zackary Drucker is positioned at the epicenter of contemporary trans cultural production in North America. On the cover of TRANSLADY FANZINE - an oversized, thick-papered photo periodical created in 2011-a 27-year-old Drucker sits naked, draped only in fur, perched atop snow-covered stadium bleachers. An intimate collaboration between Ducker and trans photographer Amos Mac, FANZINE adheres to a single subject-Drucker-and a single focus-their project co-creation (Figure 1a). In interviews about FANZINE, Mac credits early project inspiration to PINUPS, a collaboration between photographer Christopher Schulz and a single, nude male, wherein "the zine can be dismembered, and the loose pages tiled to reveal a single, monumental image of the subject," and Transsexual Illusion, a photo series from the 1990s of a transfeminine subject, captured by her transfeminine friend. Writing to Drucker in the opening pages of FANZINE, Mac names his ongoing desire to create "visual proof of our combined existence." The "our" of his sentiment is understood to be Mac and Drucker, and also the collective visual presence of trans and gender non-conforming people in public spheres. The "our" of Mac's imagination also points to the question "legible to whom?" Prior to his collaboration with Drucker, Mac was known as the co-founder and lead creative of Original Plumbing (2009-2019), a zine that featured a diversity of trans men, whom Mac photographically transformed into 1990s teen-mag-style pin-ups, alongside community-based resource sharing and writings. Proof here takes on additional meaning, as that of an ability to withstand not only the violence imposed upon subjects by historical forms of looking, but also the contemporary contexts of threat marshalled against bodies marked as trans and gender non-conforming. 


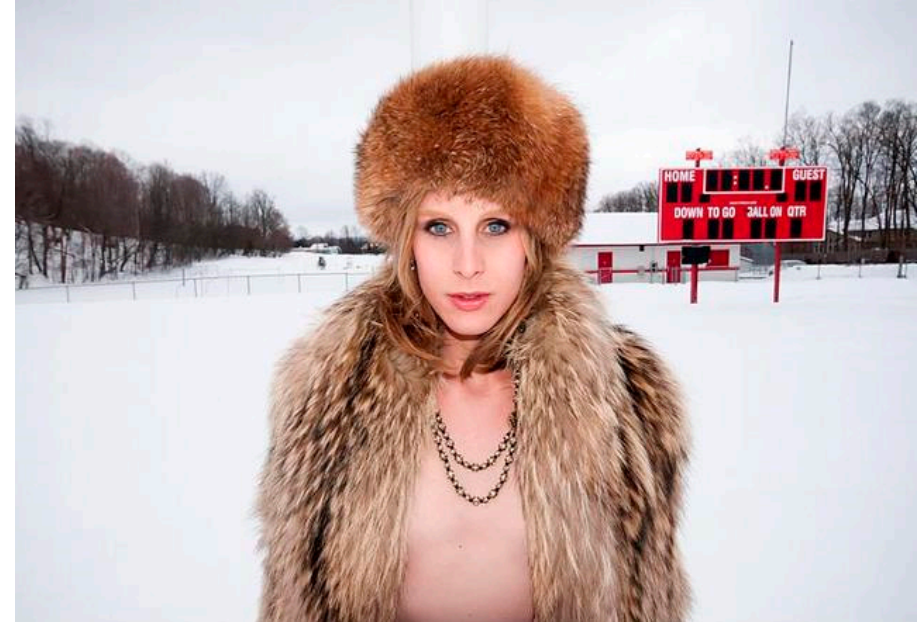

(a)

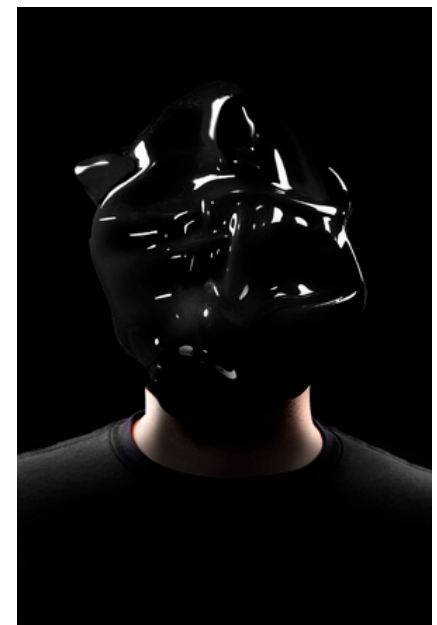

(b)

Figure 1. (a) Reproduced with permission from Zackary Drucker and Amos Mac, Translady Fanzine; published by Amos Mac, 2011 Courtesy of the Artists; (b) Reproduced with permission from Zach Blas, Facial Weaponization Suite: Mask-31 May 2013, San Diego, CA 2013, Courtesy of the Artist.

The images in FANZINE borrow from recognizable styles of fashion editorial and fetish photography, yet also resonate with the otherworldly outsider portraiture practices of Diane Arbus and Nan Goldin. Here, hierarchies of traditional photography have been evacuated of traditional meaning, as Mac inhabits a rebellious-and ultimately submissive-relation to his subject, and we learn through his writing that it was, in fact, Drucker in control of the structural apparatus, and Mac following her lead. In FANZINE, there is no true determinable subject-object relation.

About the project, Mac wonders, "When you take a photograph of someone you see in front of you, a near-stranger with a similarly unconventional path as your own, does the relationship show through the lens and onto the page of the magazine?" Throughout the collection, Drucker locks her gaze firmly to the lens, tricking - or perhaps encouraging - the viewer into believing they are the focus, when, in contradistinction, the beauty lies in the intimacy between the two makers. There is both an insularity and a performativity to this public presentation of the trans. In response to Mac's many musings on method, Drucker adds, "How do we know we exist without visual affirmation?" Followers of her artistic career can find early answers to that question in the art and archives of Mother Flawless Sabrina. Speaking and writing in the wake of Sabrina's death in 2018, Drucker shares their origin story:

Growing up, I had no access to queer subcultures, so I found my people in the world of film instead. I watched Barry Shils' 1996 documentary Wigstock on repeat, memorizing the names of the glorious queens and trans women it exalted, including heroes of mine I still idolize today: Chloe Dzubilo, Tabboo, Leigh Bowery, Candis Cayne, Lina Bradford. Van Barnes makes a gem of an appearance.

The year I moved to New York, I didn't have $\$ 20$ to get into the actual Wigstock drag festival, but I had a camera and film. I stood outside the gates to photograph performers and festival goers as they left, which felt as awkward as it sounds, until I laid eyes on Mother Flawless Sabrina. She happily consented to being photographed, pointed her finger directly in my lens and said, "you're on the wrong side of the camera, kid!" I was home.

Two planes hit the twin towers a few days later, and my fledgling adulthood smoldered in destruction and uncertainty. I taped my portrait of Flawless to the wall, directly in view of my futon on the floor, and she became this ancient mythical guardian queen watching over me as I dreamed and sexed my way into adulthood. Subconsciously, I manifested her as a leading touchstone in my life. 
Sabrina thrived within the same trans-pictorial legacy that Drucker now inhabits. A notable featured subject in early Diane Arbus photography and cameo presence in early John Waters films, Sabrina is most well-known for operating a nation-wide drag competition called the National Academy, forever-preserved in the 1968 documentary, The Queen, produced in part by Andy Warhol (see: Balzer 2005; Horak 2017). Drucker's engagement with Sabrina cannot be temporally contained. As the guest editor of a recent Aperture magazine special issue titled "Future Gender," Drucker (2017) explains "photography saved my life," as she was finally able to locate a history, a legacy and a potential within the images of trans and gender non-conforming others who came before her, even long after their passing.

\section{Photography and Scrutiny}

One of the greatest challenges to contemporary queer and feminist scholarship is to reconcile the historical project of identity politics with neoliberalism's co-optation of identity as a means to enact power through new structures of control.

$$
\text { -Blas and Gaboury (2016) }
$$

Tracing the pictorial presence of trans and gender non-conforming subjects from the clinic to the magazine affords the opportunity to chart some of the ways in which image-making has impacted rights-based social and political movements. In the case of clinical and medical photography, gender non-conforming bodies were reduced to pathology, morphology, and sex signifiers, whereas contemporary art practices by trans artists employ the very same capture-apparatus, in an attempt to restore subjectivity and agency. For Amos Mac and Zackary Drucker, photography both inverts and subverts the scrutiny and violence of looking. For Drucker and Sabrina, image-making serves as an enduring vehicle for intergenerational exchange and legacy making, further articulated in their 2011 film, At Least You Know You Exist. In each iteration, these attempts to depict the diversity of trans embodiment and experience value visibility as a marker of social progress and political potential. "We are living in a time of trans visibility," state the editors of the 2017 New Museum Anthology Trap Door: Trans Cultural Production and the Politics of Visibility, "Yet we are also living in a time of anti-trans violence" (Gossett et al. 2017, p. xv). We are compelled by the ways in which collaboration from within community systems and networks can sit in opposition to-or, perhaps, in productive tension with-the consumptive logics of commercial and capital that Trap Door critiques.

The paradoxical tension animated by these concurrent realities calls to question the power, place, and priority of visibility. While photography has a way of providing proof, the manner in which legibility is re-inscribed by new forms of institutionalization means that those incapable of being assimilated into institutional regimes remain illegible. Photography may have the power to verify one's condition-of embodiment, of affinity, of existence-but what of the unverifiable? Those who exist at the margins of institutions, subjected to what Dean Spade (2011) calls "administrative violence"? These questions and concerns inform our decisions about image reproduction in this paper. Together, we understand Drucker and Mac's project as one designed for public presentation and circulation, whereas images from The Stoller Papers were sent in private correspondence, never intended for use outside the clinic. As trans people, we recognize the violence of being looked at without consent. The relationship between visibility, representation and institutional recognition led us to think further, with the scholar-artist interventions of Zach Blas.

Writing about biometric facial recognition, Blas flags the relationship between visibility and recognition, and state and military surveillance. For Blas (2013), "the very meaning of a face-what it is, does, and communicates-is continuously redefined" by its use-value for future governance. His project, "Facial Weaponization Suite (2011-2014)" is a series of community-based workshops that amasses biometric facial data from a group of participants to create "collective masks" that are unrecognizable to recognition software (Figure 1b). Each mask in the series addresses scientific and/or cultural assumptions and anxieties—about race, gender, sexuality, religion_-which assume 
something might be quantifiable or known by assessing the details of a face. Charting connections between multiple - at times overlapping — vulnerable populations, Blas contends that working against representation (see: Holmes 2014) and identification is a new and necessary mode for minoritarian-group power and survival (see: Beauchamp 2009; Spade 2011). Further, he argues that defacement, and/or $a$ failure to be recognized or captured-popularized in media by activist groups such as Anonymous, black blocs, the Zapatistas, and Pussy Riot-is a critical mode of contemporary resistance (Blas 2013). With a nod to Jack Halberstam's (2011) work on queer failure, Blas argues that "queer failure engages political and social change differently than policy; attention is not given to legal reform but to styles of living as disorderly and uncompromising (anti-)aesthetics and (anti-)politics." For Halberstam and Blas, failure-whether it be queer or biometric-renders one opaque, illegible, and therefore charged with new political potential. The opportunity to become faceless, for Blas, offers "a political transformation into what is unknown," even as he acknowledges that "invisibility is often an unequally distributed privilege" (Blas and Gaboury 2016, p. 156; see also: Spade 2011).

\section{Photography and Failure}

Realness - the appropriation of the attributes of the real, one could say-is precisely the transsexual condition. The real, on the other hand, is that which always exists elsewhere, and as a fantasy of belonging and being ... The ever receding horizon of the real, however, need not be the downfall of the transsexual aspiration; indeed, it may be its strength.

-Halberstam (2005, p. 52)

Facial recognition software is as yet unable to account for a face in transition (Gault 2019), just as photography fails to render legible transness. Because the medical establishment-from the era of the clinic to the present-has controlled the language of sex and gender, trans people have oft struggled to articulate their lives and subjectivities against the grain, influence, and gaze of the medical apparatus. Metaphorizing transsexuality with the monster of Victor Frankenstein, Susan Stryker (2006, p. 247) argues that, while the monster in Mary Shelley's Frankenstein rebels against his creator by mastering language, the transsexual struggles to master speech because of "the inability of language to represent the transgendered subject's movement over time between stably gendered positions in a linguistic structure." She continues, "The sounds that come out of my mouth can be summarily dismissed as the confused ranting of a diseased mind" (Stryker 2006, p. 249). Filtered through the language of pathology, any transsexual speech act can become contorted, wielded as verification of some unnatural condition. Language offers the possibility of claiming personhood, while simultaneously opening room for institutional diagnosis (see: Salah 2014). In the midst of language's limitations, we have traced the frequent turn to the photographic, yet uncovered a subsequent return to text.

In Second Skins, Jay Prosser (1998) engages transition photographs as a means to access the trans real. Rebutting Judith Butler's theory of gender performativity, Prosser offers transness a kind of ontological legitimacy. Writing in 1998, he attempted to express the embodied experience of transition outside the realm of the linguistic by citing photos he felt captured the trans real. Later, he would return to his own work in "A Palinode on Photography and the Transsexual Real," and remark: "What strikes me now about the real—and it's so obvious that I'm dumbfounded I couldn't see it before-is that it is precisely our failure to achieve the real that makes us desire it" (Prosser 1999, pp. 89-90). In Prosser's re-assessment of his original thesis, he too notices the way in which captions operate, and marks the necessity of the sexed body to be described.

While Prosser was writing 20 years ago, long before the birth of trans studies in the academy and the so-called tipping point of trans visibility in media (Steinmetz 2014), we find instructive guidance in his early inquiries. Speaking to Artforum in 1971, Diane Arbus hinted, "A photograph is a secret about a secret. The more it tells you the less you know." The failure of transsexuals to be real, and of photographs to capture the truth of trans experience, endures as both an opening and a shield, and we have found no better summary of the paradoxical relationship between the visual and the visible. 
Author Contributions: Writing—original draft, C.J. and E.H.D.; Writing—review \& editing, C.J. and E.H.D.

Funding: This research received no external funding.

Acknowledgments: The authors thank Kristen Schilt, Naomi de Szegheo-Lang, Melissa Ragain, Colin Chen, and the anonymous peer reviewers for their instructive and generative feedback.

Conflicts of Interest: The authors declare no conflict of interest.

\section{References}

American Psychiatric Association. 1980. Diagnostic and Statistical Manual of Mental Disorders, 3rd ed. Washington: American Psychiatric Association.

Anex-Ries, Quinn, Emmett Harsin Drager, Chase Joynt, and Zackary Drucker. Forthcoming. Agnes and Her Afterlives: Transsexual Archives, Lost and Found. International Journal of Communication.

Arbus, Diane. 1973. Diane Arbus: An Aperture Monograph. New York: Aperture.

Balzer, Carsten. 2005. The Great Drag Queen Hype: Thoughts on Cultural Globalisation and Autochthony. Paideuma 51: 111-31.

Barthes, Roland. 2010. Camera Lucida: Reflections on Photography. New York: Hill and Wang.

Beauchamp, Toby. 2009. Artful concealment and strategic visibility: Transgender bodies and US state surveillance after 9/11. Surveillance \& Society 6: 356-66.

Benjamin, Harry, Gobind Behari Lal, Richard Green, and Robert E. L. Masters. 1966. The Transsexual Phenomenon. New York: Julian Press, vol. 966.

Blas, Zach, and Jacob Gaboury. 2016. Biometrics and opacity: A conversation. Camera Obscura: Feminism, Culture, and Media Studies 31: 155-65. [CrossRef]

Blas, Zach. 2013. Escaping the Face: Biometric Facial Recognition and the Facial Weaponization Suite. NMC Media-N, CAA Conference Edition. Available online: http://median.newmediacaucus.org/caa-conferenceedition-2013/escaping-the-face-biometric-facial-recognition-and-the-facial-weaponization-suite/ (accessed on 1 September 2019).

Davis, Bob. 2015. Using Archives to Identify the Trans* Women of Casa Susanna. TSQ: Transgender Studies Quarterly 2: 621-34. [CrossRef]

Drucker, Zackary. 2017. "Future Gender" An Aperture Monograph. New York: Aperture.

Drucker, Zackary. 2018. THEM. Available online: https://www.them.us/story/mother-flawless-sabrina-the-queericon-who-taught-me-how-to-live (accessed on 1 August 2019).

Foucault, Michel. 1994. The Birth of the Clinic: An Archaeology of Medical Perception. New York: Vintage Books.

Gault, Matthew. 2019. Facial Recognition Software Regularly Misgenders Trans People. VICE. Available online: https://www.vice.com/en_us/article/7xnwed/facial-recognition-software-regularly-misgenders-transpeople (accessed on 1 August 2019).

Gossett, Reina, Eric A. Stanley, and Johanna Burton. 2017. Trap Door: Trans Cultural Production and the Politics of Visibility. New York: New Museum.

Halberstam, Jack. 2005. In a Queer Time and Place: Transgender Bodies, Subcultural Lives. New York: NYU Press.

Halberstam, Jack. 2011. The Queer Art of Failure. Durham: Duke University Press.

Holmes, Emily K. 2014. Locating Technology: Against Recognition. Art Practical. Available online: https: //www.artpractical.com/column/locating-technology-against-recognition/ (accessed on 1 September 2019).

Horak, Laura. 2017. Tracing the History of Trans and Gender Variant Filmmakers. Spectator 37: 9-20.

Hurst, Michel, and Robert Swope. 2005. Casa Susanna. Brooklyn: PowerHouse Books.

Jay, Martin. 1994. Downcast Eyes: The Denigration of Vision in Twentieth-Century French Thought. Berkeley: University of California Press.

Joynt, Chase, and Kristen Schilt. 2015. Anxiety in the Archive. TSQ: Transgender Studies Quarterly 4: 635-44. [CrossRef]

Joynt, Chase, and Kristen Schilt. 2018. Framing Agnes, (short film).

Malatino, Hilary. 2019. Queer Embodiment: Monstrosity, Medical Violence, and Intersex Experience. Lincoln: University of Nebraska Press.

Meyerowitz, Joanne. 2002. How Sex Changed: A History of Transsexuality in the United States. Cambridge: Harvard University Press. 
Prosser, Jay. 1998. Second Skins: The Body Narratives of Transsexuality. New York: Columbia University Press.

Prosser, Jay. 1999. A Palinode on Photography and the Transsexual Real. a/b: Auto/Biography Studies 14: 71-92. [CrossRef]

Salah, Trish. 2014. Subaltern. TSQ: Transgender Studies Quarterly 1: 200-4. [CrossRef]

Sandals, Leah. 2016. When a Private Trans Archive Becomes Public Art. CanadianArt. Available online: https: //canadianart.ca/features/when-a-private-trans-archive-becomes-public-art/ (accessed on 1 August 2019).

Singer, Benjamin. 2006. From the Medical Gaze to Sublime Mutations: The Ethics of (Re)Viewing Non-normative Body Images. In The Transgender Studies Reader. New York: Routledge, pp. 601-20.

Spade, Dean. 2011. Normal Life: Administrative Violence, Critical Trans Politics, and the Limits of the Law. Brooklyn: South End Press.

Steinmetz, Katy. 2014. The Transgender Tipping Point. Time Magazine 183: 38-46.

Stryker, Susan. 2006. My Words to Victor Frankenstein Above the Village of Chamounix: Performing Transgender Rage. In The Transgender Studies Reader. New York: Routledge, pp. 244-56.

Terry, Jennifer. 1990. An American Obsession: Science, Medicine, and Homosexuality in Modern Society. Chicago: University of Chicago Press.

Warner, Michael. 2002. Publics and Counterpublics. New York: Zone Books.

(C) 2019 by the authors. Licensee MDPI, Basel, Switzerland. This article is an open access article distributed under the terms and conditions of the Creative Commons Attribution (CC BY) license (http://creativecommons.org/licenses/by/4.0/). 